Sylwia Pietrowiak

Uniwersytet Gdański

\title{
Błędne koło błazna, czyli krok wstecz z letniej kuchni Gulnary ${ }^{1}$
}

\section{Zamiast wstępu}

$\mathrm{T}^{\mathrm{o}}$ o nie jest tekst o celach i wynikach. Pozwolę sobie również nie wprowadzać czytelnika w region, pole badawcze czy tezy. Mam jednak ku temu pewne powody. Tego o czym tu piszę, mimo iż osadzone w konkretnych realiach, doświadcza zapewne większość etnografów, niezależnie od miejsca, w którym prowadzi badania, i jest to poniekąd doświadczenie uniwersalne. Jednak nie jest to również tekst o doświadczeniu, choć niewątpliwie porusza tę kwestię. Czym zatem jest? Jest wspomnieniem, refleksją, negacją i potwierdzeniem tez, których teraz unikam, a przede wszystkim wędrówką. Chciałabym, aby czytelnik poczuł się tak jak ja, żeby doświadczył dyskomfortu, żeby był zagubiony, by nie wiedział przez chwilę, gdzie się znajduje, by odbył ze mną wędrówkę, która jest wartością niezależnie od celu, do którego zmierza. Cel ten jest oczywiście ważny, ale nabiera sensu i głębszego znaczenia dopiero po przebyciu choć fragmentu drogi - drogi, która się nie kończy.

\section{5 lipca 2014 roku, Gulnara}

Gulnara cieszy się, że przyszłam, gości mnie przez dwa dni: robi dla mnie manty bez tłustego mięsa, pieczony drób, pizzę. Nie robi beszbarmak ${ }^{2}$ - chociaż teściowa napomina ją, że powinna. Dziękuję jej za to uprzejmie i błogosławię w duchu. Muszę też głośno powiedzieć o tym przy teściowej. Gulnara na moją prośbę opowiada, jak wyszła za mąż. Opowiada ciekawie, szczerze i energicznie. Gulnara

1 Wszystkie imiona z poniższym tekście są zmienione.

2 Określane jako tradycyjne danie kirgiskie. Przyrządzane jest $\mathrm{z}$ gotowanej w jednym garnku baraniny z makaronem pokrojonym na szerokie plastry. Nazwa beszbarmak oznacza pięć palców i pochodzi od sposobu jedzenia tego dania, które spożywa się dłonią (nie używając sztućców). W opinii Kirgizów, u których gościłam, daniem tym należy częstować gości, podaje się je też na wszelkiego rodzaju świętach. 
jest szczupła, drobna i bardzo silna. Ubiera się jak niezamężna dziewczyna, może nosić spodnie, ale zakłada chałat i chustkę na głowię, gdy przychodzą krewni męża. Robi jednocześnie pranie, przebiera dzieci, zmywa naczynia, piecze chleb, przygotowuje kolacje, przynosi sweter dla teściowej, doi krowę, karmi cielaka, biegając we wszystkie strony świata. Nie ustała w ciągu tych dwóch dni, wstając pierwsza i kładąc się spać ostatnia.

Pamiętam jej okrągłą twarz, gdy mieszkała jeszcze w Biszkeku, gdzie studiowała i pracowała w sklepie rodziców. Kim jest Gulnara? Jest Kirgizką, czyli kim? Ma ciemne oczy, ciemną skórę i ciemne lekko skośne oczy. Ma dziewczęce dołki, kiedy się uśmiecha i próbuje sobie wszystko tłumaczyć. Czytuje w internecie sentencje sławnych lub domorosłych myślicieli, dostosowując je do swojej sytuacji. Była nastolatką, która wyjaśniała nam, jak powinny zachowywać się kobiety, kiedy pierwszy raz przyjechałam z innymi do Kirgistanu. Nie wiem dlaczego uraczyła nas tym savoir-vivrem, może zachowywałyśmy się niestosownie, ale od tego czasu zawsze staram się tam siedzieć tak, jak przystoi kobiecie - katując kolana i kręgosłup. Kim była wówczas Gulnara? Była Kirgizką - dorastającą, pulchną panną uczącą się w stolicy, ciekawą świata i ambitną dziewczyną.

\section{Goście}

Kucam przy szafce letniej kuchni Gulnary i płaczę. Za kuchnią są goście: mężczyźni strzelają z wiatrówki do ptaków i puszek, kobiety siedzą w ogrodzie, rozmawiając. Dzieci mówią, biegają, plamią, krzyczą, jedzą. Dziewczynka ciągnie róg pościeli, brudząc schnące pranie, jej ojciec odwracając głowę od wiatrówki, woła żonę. Gulnara z rękami oklejonymi ciastem i mąką ratuje pościel przed zabrudzeniem i odciąga dziecko $\mathrm{w}$ inną stronę. Wszyscy odpoczywają. Tylko Gulnara pracuje, tylko dla niej nie ma miejsca na wytchnienie...

Napisałam obiektywizującą pracę magisterską ${ }^{3}$, skupiając się na porwaniach panien $\mathrm{w}$ celach matrymonialnych i roli kobiety $\mathrm{w}$ rodzinie $\mathrm{w}$ szerszym kontekście społecznym, analizując szczegółowo śluby zawarte poprzez porwanie oraz następujące po nich kolejne etapy życia kobiety. Wnioski, do jakich doszłam, były takie, że kobieta w kirgiskiej rodzinie to osoba wykazująca dużą, większą niż się powszechnie uważa, podmiotowość. Zaznaczałam to podczas każdej mojej publicznej wypowiedzi dotyczącej Kirgizów, próbując wytłumaczyć zawiłe relacje w poznawanej przeze mnie społeczności. Owe tezy będące w opozycji do tego, co zwyczajowo myśli się w szeroko pojętych środowiskach zachodnich, są również sprzeczne $\mathrm{z}$ werbalizowaną opinią samych Kirgizów, gdzie to mężczyznę nie kobietę przedstawia się w sferze publicznej jako osobę sprawczą i decyzyjną. Teraz jednak siedzę na kirgiskim podwórku, z młodą mężatką i nie

3 Pracę o tytule Małżeństwo przez porwanie w regionie Kara-bura w pótnocno-zachodnim Kirgistanie. Uspołecznianie przemocy, oswajanie obcości i przywracanie podmiotowości napisaną pod kierunkiem prof. Zbigniewa Jasiewicza obroniłam w 2011 r. w Instytucie Etnologii i Antropologii Kulturowej UAM. 
wiem, kim właściwie jestem, by oceniać i wartościować postawy i sposoby bycia w świecie, by interpretować, stawiać wnioski i odpierać ataki zachodnich punktów widzenia. Dziewczyna ściska mnie za rękę i gorączkowo zaczyna się zwierzać, tak jakby moje nieadekwatne do sytuacji zachowanie uwolniły ją od bycia twardą. "Czasami czuję się jak robot, tylko pani mogę to powiedzieć". Widzę jak zaszkliły jej się oczy. Ta wesoła, energiczna i rozsądna młoda mężatka, matka dwójki dzieci odsłania przede mną, ukrytą przed innymi, sferę swojego życia i to za sprawą mojej słabości. Mówi mi wszystko to, co jest dalekim wspomnieniem dla wielu dojrzałych kobiet, a dla niej chwilą obecną. Mówi tak, jak do tej pory nie mówiła do mnie żadna kirgiska kobieta. Patrzę na nią zdumiona. Jak ja nie pasuję do tych ludzi, jak bardzo ciągle jestem tu obca. Pamiętam dzieci, które teraz są już dorosłymi, pamiętam ciąże kobiet, których owocem są kolejne pokolenia społeczności, pamiętam młodsze twarze, mniej spracowane dłonie, przyjęcia, pragnienia, obietnice. Czas mija, a ja ciągle jestem nie na miejscu, ciągle tam nie pasuję i ciągle niczego nie rozumiem. Za każdym razem, dowiadując się coraz mniej, zaczynam myśleć, że nie mam prawa do wygłaszania opinii o tych ludziach. Kolejne pytania, bezradność i nieumiejętność bycia. Jakbym była coraz bardziej zachodnia, coraz bardziej feministyczna. Jakbym była jednocześnie zbuntowana wobec ich wyobrażeń o mojej osobie, o mojej kulturze, coraz bardziej zbuntowana wobec ich kultury, coraz bardziej zbuntowana wobec swojej. Pisząc o Kirgizach, zawsze zostawiałam szerokie pole do namysłu i refleksji innym, nie broniąc, nie oskarżając, nie narzucając, ale dając do myślenia, ofiarowując narzędzia do wyzbycia się tej egocentrycznej skorupy, w której każdy z nas siedzi i nie potrafi się z niej wydobyć.

Czy będąc człowiekiem z zewnątrz, mogę sobie pozwolić tylko na garść krytycznej refleksyjności? Jak dać szansę Innym na tego typu samookreślenie, jakie dają badania Kaupapa Maori ${ }^{4}$ - czy taki sposób jest prawdziwy? Co by powiedzieli Kirgizi o porwaniach, o pozycji kobiety? Oczywiście pytam Ich o to, nagrywam, zapisuję, ale wyciągam swoje tezy i swoje wnioski. Naznaczone nie tylko ciężarem polskiej specyfiki, ale i własnych doświadczeń życiowych. Jednak w dobie krytyki neokolonialnej etnografii zadaję sobie również pytanie o sensowność negowania tych punktów widzenia. Czyż nie są one bogactwem, nawet jeśli naznaczone są tym wszystkim o co są oskarżane? Czy faktycznie kreuję wiedzę, marginalizując głos tubylców, umniejszając wartość ich wiedzy, a umacniając wiedzę i paradygmaty kolonialne, dla własnych, jak pisze Bishop korzyści? Stawia cudzysłów w słowie ekspert i zadaje pytanie, wobec kogo badacze są odpowiedzialni? Gdzież są moje korzyści? Wobec kogo jestem odpowiedzialna, jeśli sama inicjuję i realizuję badania? Kim jesteśmy my - osoby, które mówią, że prowadzą badania antropologiczne? Cóż to właściwie znaczy? Jak wysoko ustawiamy siebie $\mathrm{w}$ relacji z Innym, że śmiemy mówić o badaniach. Jestem zatem, jak chce Zygmunt Bauman, "turystą" swobodnie przemieszczającym się za

4 Podejście w badaniach ludu tubylczego Nowej Zelandii, w którym neguje się wartość zachodnich narracji, promuje się samookreślenie uczestników badań (Bishop 2014). 
głosem serca, a stojącym w opozycji do tych, którzy skazani są na pozostanie w lokalności. Będąc tą uprzywilejowaną częścią globalnej kultury kapitalizmu, nie potrzebuję wizy, by przekroczyć granice Kirgistanu. Kirgizi, by przyjechać do Polski, muszą mieć zaproszenie. Podział ról (jak może się wdawać) jest jasny, ale znowu to zrobiłam. Kirgizi nie potrzebują wizy do Rosji - ja potrzebuję. Dlaczego uznałam, że zachodni świat jest uprzywilejowaną częścią świata? Życie, twierdził Czesław Robotycki (2012), jest nieustanną grą, w której odgrywamy rozmaite role. Dlaczego zatem nie potrafię przyjąć żadnej z nich?

Ciągle przyłapuję się na dumnym przekonaniu o własnej etnologicznej wyjątkowości. Przecież nie jestem zwykłym badaczem zachodnim, jestem osobą, którą pragnienie zrozumienia i zaistnienia $\mathrm{w}$ innym kontekście kulturowym przywiodło na kirgiską wioskę. Tracącą na to oszczędności, zdrowie oraz poświęcając czas przeznaczony na odpoczynek. Kobietą z kraju, podobnie jak Kirgistan, okaleczonego komunizmem. Jednak okaleczonego inaczej, zupełnie inaczej. Nawet jeśli przez chwilę poczujemy okraszone wódką braterstwo, śpiewając wspólnie Pust' vsegda budet solnce ${ }^{5}$, to zniknie ono tuż za rogiem pomnika Lenina wciąż stojącego przed domem kultury, zniknie za rogiem przygniecionej kamieniem sukni świeżo poślubionej porwanej kobiety, za progiem nowego meczetu, po przejściu na ojczysty język. Nadal będziemy zupełnie innymi Innymi - ja i Oni.

\section{7 czerwca 2014 roku, Biszkek}

Siedzę na rozgrzanym, wysokim krawężniku i czekam na Kurmanbeka, który miał po mnie przyjechać. Za mną lotnisko Manasa, a wokół mnie grupa taksówkarzy, którzy chcą, bym skorzystała z ich usług. Mówię im, że czekam na kogoś i w końcu się poddają. Jeden $\mathrm{z}$ nich ciągle mnie namawia, bym pojechała z nim nad jezioro Issyk-kul, wspomina coś o masażach i przyjemnym spędzaniu czasu. Pytam skąd przeświadczenie, że mogłabym się na to zgodzić. Ogląda telewizję, czyta gazety, więc wie, jak zachowują się zachodnie kobiety. W końcu mu mówię, że chyba mnie nie szanuje i że do Kirgizki nigdy by tak nie powiedział. Szacunek to dla miejscowych - jak zawsze uważałam - słowo kluczowe, więc mężczyzna wygląda na zmieszanego. Obserwuje mnie, pyta ile mam lat, mówię $\mathrm{mu}$, a on nie wierzy. Daje mi startową kirgiską kartę do telefonu i dzwonimy razem do Kurmanbeka. Przekonuje mnie, że Kurmanbek słabo mówi po rosyjsku, więc nie będę $\mathrm{z}$ nim miała o czym rozmawiać. Zupełnie nie przyjmuje do wiadomości, że może mnie urazić. Czy bycie „zachodnią turystką" czyni ze mnie osobę o konkretnych znamionach? Moja wiedza o panujących tu obyczajach nie zmienia mnie $\mathrm{w}$ jego oczach. Jestem tylko zachodnią kobietą, która ma inną moralność i odmienne wartości niż lokalne kobiety. Patrząc na to obiektywnie, to ma przecież rację i ja nałożyłam na niego znamiona. Założyłam, że jest Kirgizem, o wartościach jakie są mi znane. Pyta, co będę robić, mówię, że jadę na wieś, będę

\footnotetext{
5 Transliteracja wg międzynarodowej normy ISO 9.
} 
tam jadła barany i odpoczywała od miasta. Chyba mówię mu to po to, by mu udowodnić swoją odmienność od "zwykłych zagranicznych gości”, a on powraca do swojej propozycji, że lepiej pojechać nad Issyk-kul - tam się odpoczywa, nie na wsi. Twierdzi, że jest w połowie Kazachem i że baranina dla niego śmierdzi nie jada jej - jakby dawał świadectwo, że to co miejscowe nie jest jego udziałem. Sugeruje, że to, co normalne dla mnie - zachodniej kobiety - jest normalne dla niego. Jakbyśmy oboje przybierali role, których oczekujemy od siebie. On, że jest bardziej zachodni niż tutejszy, ja natomiast, że jestem bardziej tutejsza niż zachodnia. Pytam o wojska amerykańskie stacjonujące niedaleko lotniska. Dowiaduję się, że wyjechały dwa miesiące temu. Kontrakt się skończył i nie podpisali nowego. Tyle lat i w końcu wyjechali, a mówiło się, że kirgiski rząd chce służyć dwóm bogom: Rosji i USA. Mężczyzna wnikliwie mnie obserwuje. Ciekawe, co tak naprawdę o mnie myśli, dlaczego ma to dla mnie znaczenie? Pojawia się Kurmanbek, a mi się wydaje, że taksówkarz patrzy na niego i jego stary samochód nieprzychylnym okiem. A może to moje nieprzychylne oko? Samochód nie ma klamek, silnik odpalił dopiero za kolejną próbą, a na tylnym siedzeniu i podłodze jest pełno pustych opakowań po przetworach mlecznych. Odjeżdżamy. Patrzę na okurzone miasto i mówię, że mi się podoba. Cóż mam powiedzieć. Oboje zresztą nie wiemy co mówić...

Tak już będzie do końca: próba głaskania po udach, wciągnięcia do rzeki, kradzież. Jedziesz sama do kraju muzułmańskiego - tego powinnaś się spodziewać. Pierwszy raz $\mathrm{w}$ ciągu tych kilku wyjazdów poczułam to, przed czym przestrzegali inni, czego sama się obawiałam zanim czegokolwiek dowiedziałam się o Kirgizach, a co stawało mi się obce w miarę jak ich poznawałam. Co takiego zaszło tym razem, ja się zmieniłam, czy Oni? Jestem starsza, myślałam, że przez to bardziej bezpieczna. Przejechałam samotnie: pociągami przez Kazachstan, z Osz do Tałasu, z Lasy do Pekinu - bez poczucia takiego etykietowania. A może ono było, tylko nie potrafiłam go dostrzec? Może to kolejna lekcja, nic nie jest oczywiste, wszystko jest w kontekście - również moim - i wszystko się zmienia.

\section{W Kirgistanie porywa się kobiety w celach matrymonialnych}

To nie tylko fakt, ale również moje dawne stanowisko w tej kwestii. Sprowadzało się tylko do tego stwierdzenia. Pierwszy pobyt w tym miejscu zwyczajnie utwierdził mnie, że faktycznie tak jest. I to właściwie wszystko. Nie potrafiłam się oburzać. Od tego czasu przybyłam długą drogę, którą wciąż się poruszam, odkrywając złożoność sposobów bycia w świecie Innych, jak i mój sposób bycia w świecie. Faktem jest, że kobiety się porywa, a ich reakcje przeważnie są takie same. Płaczą i krzyczą podczas uprowadzenia i tego właściwie się od nich oczekuje. Ten skomplikowany i wielowymiarowy obyczaj wzbudza wiele emocji wśród przedstawicieli zachodniej kultury, którzy jako propagatorzy wolności, samostanowienia i współcześnie pojmowanego bytu jednostkowego skupiają się na tych jego aspektach, które są dla nich najbardziej rażące. 
Tak, rozmawiałam z kobietami, które opowiadały o swoim porwaniu i późniejszym życiu $\mathrm{w}$ rodzinie męża. Tak, potwierdzały, że płakały i nie chciały zostać. Tak, wspominały o trudnym, początkowym życiu małżeńskim. Tak, mówiły, że nie chciały, by noc nastąpiła, że nienawidziły swojego męża. Tak, byłam na ślubie, gdzie porwano dziewczynę, widziałam jak płakała, jak została siłą zmuszona do przyjęcia błogosławieństwa, jak przyjechała jej matka i powiedziała „zostań". Widziałam to wszystko, a jednak uparcie powtarzałam tezę o znaczącej roli kobiety w tej społeczności.

Uczestnictwo $\mathrm{w}$ ślubie zawartym poprzez porwanie to doświadczenie nieopisywalne. Mówiłam o tym ${ }^{6}$, jak bezdusznie rejestrowałam wydarzenia w tym najtrudniejszym dla panny czasie, gdy ją przywieziono do domu porywaczy, nakłaniano do założenia ślubnej odzieży, poddania się obrzędom. Stojąc wśród Kirgizów w tym jednocześnie fantastycznym i tragicznym dla mnie momencie, wypełniałam zadanie. Właściwie po to tam byłam. Mówiłam też o tym, że mimo tego wyrachowanego zachowania coś we mnie się przełamało, coś co wcześniej było tylko przyjęciem do wiadomości tego "niehumanitarnego" zwyczaju. Byłam wówczas rozczłonkowana między tym, co mi obce, tym co autopsyjne, tym co powinnam zrobić, tym czego nie powinnam zrobić i tym, czy w ogóle tam jestem. Jakbym była jednocześnie w środku i na zewnątrz. Jakbym była porwaną dziewczyną i porywaczami, jakbym była panem młodym i kobietami przymuszającymi pannę do wszystkiego, czego zrobić nie chce, jakbym była jej siostrą, która kiedyś też była porwana, jakbym była jej bratem, który jest wściekły, jakbym była jej matką, która mówi „zostań”. Byłam wówczas tymi wszystkimi ludźmi i widziałam, dużo widziałam, jakbym zażyła jakiś narkotyk pozwalający dostrzec każdy gest, każdy ruch, ale wiem - to było złudzenie: ...turkusowa sukienka, brudne klapki, sandały i męskie lakierki układane na progu, brązowe karki kucających, czerwone mięso, wiadro z wodą burą od krwi, plastikowa płachta na plecach błogosławionych, góra ciasteczek, równiutko ułożone manty, dzieci tulące się do kobiecych nóg...

Zapamiętałam wiele szczegółów, ale to moje szczegóły, szczegóły Innych pozostały dla mnie niedostępne.

Owo bycie „wszystkimi” pozwoliło mi wyjść poza to, o czym możemy przeczytać w każdej publikacji na temat porwań. Okrutny, barbarzyński zwyczaj, podczas którego dochodzi do przemocy i gwałtu, a więc łamania praw człowieka. Tylko jak to się ma do kirgiskich standardów? Używając znanej na zachodzie retoryki, nie dostrzeżemy niczego więcej niż tego chcemy. Dostrzeżemy tylko to, co najmocniejsze - co godzi w nasze ego.

W porwaniu i ślubie uczestniczy nie pan młody-porywacz i jego ofiara-panna, ale cała społeczność, w której konkretne jednostki pełnią określone funkcje.

6 Wystąpienie konferencyjne: 20-21 marca 2012 r., pt. Wiedzieć, a doświadczyć, czyli o tym jak pozostałam bierna, kiedy porwano kirgiską dziewczynę. Uniwersytet Szczeciński, VI Międzyuczelniana Konferencja Antropologiczna. Teren w ścisłym tego słowa znaczeniu. Badania terenowe od „kuchni". 
Tego oczywistego faktu nie dostrzegłabym, gdybym tam nie trafiła. Mogłam go również nie zauważyć, gdybym skupiła się tylko na pannie, ignorując zupełnie wszystkie inne osoby, uznając je z góry za antagonistów. Mogę sobie dzisiaj zadawać pytanie, gdzie jest moja granica przyjmowania tego, co nieeuropejskie, przyjmowania z przerażeniem, ale i akceptacją - nic nie zrobiłam, by pomóc dziewczynie. Ten paraliż połączony z fascynacją można by nazwać okrucieństwem, ale czym był w istocie? Próbuję w znanym mi zasobie słów przetransformować tamto doświadczenie $\mathrm{w}$ gęsty opis, $\mathrm{z}$ góry skazując to zadanie na niepowodzenie. Taka absorpcja nie zdarzyła mi się nigdy przedtem ani potem. Usprawiedliwiam się czasami przed sobą słowami dziewczyny, którą odwiedziłam rok po ślubie. Cytuję jej słowa, które rozbawiają odbiorców i spłaszczają to, co istotne. Ale robię to, na przekór, chcąc - jak błazen Kołakowskiego podważać wszystkie krytyczne i bezrefleksyjne opinie: Sami smotrite kakoj krasavčik! $!^{7}$

\section{8 rok, etnograficzny czas zasłyszany}

Leżę, boli mnie głowa. Już się nie przejmuję, że znowu ogarnęła mnie słabość. Oni przyzwyczaili się, dostałam poduszkę i koc. Poduszka jest przyjemnie zimna, słyszę głosy: staruszka, dziewczynka, kobieta. Zatapiam się w głowie i w poduszce, zastanawiając się, dlaczego nie mogę tu normalnie funkcjonować, kiedy to minie, kiedy wrócę do domu. Jednak w tej chwili jest mi dobrze tu gdzie jestem teraz. Poduszka robi się ciepła, przesuwam głowę kawałek dalej, ogarnia mnie stan czuwania naznaczony przytłumionym bólem i jakimś bezpieczeństwem. Słyszę jak trzy pokolenia rozmawiają. Nie rozumiem słów, ale ich ton jest zwyczajny... dzieje się zwyczajny dzień... słyszę odgłosy naczyń, plusk wody, kroki...

jeśli kobieta będzie szanować męża to i on będzie ją szanował, a później inni będą szanowali kobietę, jednak to ona pierwsza musi okazać szacunek

już się nie boję mojego męża

na początku, codziennie płakałam

teraz jestem samodzielną gospodynią

- A co to jest szacunek? Co to znaczy szanować męża?

słuchać go, nie robić niczego wbrew jego woli

mój mąż jest bardzo zaradny

to mąż mnie nauczył jak być kobietą, jak sobie radzić w życiu

już jako dziecko, ojciec wysyłał go, jeśli miał jakąś sprawę do załatwienia

tylko on ze wszystkich braci umie prowadzić ciężarówkę, dlatego to u nas stoi.

Wieczorem wrócił ojciec rodziny z pola, dzieci podają mu stołek, największe kawałki mięsa, odmawiając sobie. Żona nalewa zupę i herbatę, łamie na kawałki chleb i kładzie blisko męża...

\footnotetext{
7 Proszę zobaczyć jaki z niego przystojniak.
} 
Budzę się, ktoś płacze. Mężczyzna-mąż przyszedł pijany do domu, zachowuje się jak dziecko, płacze, uderza w przedmioty, przewraca się, płacze ponownie. Żona, bez słowa, wykonuje swoje zajęcia. Dzieci siedzą cicho w jednym miejscu. Mężczyzna miota się po mieszkaniu, wykrzykując i płacząc, a staruszka uspokaja go głosem kochającej matki. Wypowiada zdrobniale jego imię, "wiem”, że go głaszcze. Kątem oka widzę, jak gospodyni zawsze wesoła, zawsze na wszystko reagująca, teraz nic nie robi, nie krzyczy, nie lamentuje, nie komentuje, nie próbuje rozmawiać, nie pomaga teściowej zaprowadzić pijanego do łóżka, omija ciało głowy rodziny, wykonując rutynowe zajęcia domowe. Boję się ruszyć, boję się spojrzeć jej w twarz. Słyszę, jak matka prowadzi syna do sypialni, uspokajając go głosem. Jakże mnie zadziwia ten ton pasujący raczej do tego, by kierować go do sześciolatka, który potłukł kolana. Kolejny raz zaskoczyła mnie ta staruszka. Krzyki i płacz usłyszę jeszcze kilka razy, jednak nie odważę się podnieść z poduszki. Czuję się winna, że tu jestem, że słyszę, że tak jak gospodyni udaję, że nic się nie stało.

Mąż ucichł, a po mnie przyszła kobieta, zabierając na urodziny starej Rosjanki z Tuwy. Zmuszam się, by wstać i udać się w kolejną wyprawę do świata ludzi nieznanych, by w ich kuchniach, sypialniach i podwórkach udawać, że mnie nie ma. Nie odważyłam się zapytać nikogo o ten czas naznaczony bólem głowy, głosami i wspomnieniami słów z rozmowy przeprowadzonej kilka dni temu. Jednak myślałam o nich dużo i myślę o nich teraz, zastanawiając się nad tym, o co bałam się zapytać.

Odpowiedzi poszukuję w byciu z Innymi, w analizie życiorysów, w przypadkach jednostkowych, które są częścią całego układu. Poszukuję ich również w sobie, wciąż negując własne punkty widzenia, własne odniesienia, własny życiorys. Ciągle muszę siebie pilnować, by nie zatracić się w Innych, by nie zatracić siebie.

\section{Kiedy wejdziesz między wrony... 29 czerwca 2014 roku}

Jaka jest Twoja żona? ...nie będę chwalit... (i bardzo cicho, ledwo słyszalne), mala$\operatorname{dec}^{8}$... (i znowu jakieś pochwalne słabo rozumiane szepty) Moja szkoła! - to wypowiada głośno. Śmiejemy się oboje. Ja się śmieję dlatego, że rozmówca potwierdza słowa żony, a może dlatego, że przyjęłam na chwilę ich perspektywę. A on się śmieje dlatego, że te słowa potwierdzają... no właśnie cóż one potwierdzają?

„Kobieta jest jak źrebak, nic nie wie o życiu” - przywołuję w myślach krytykowane przez Cruz Leo (2013: 25) słowa bohatera filmu szykującego się do ożenku. Każdy może w nich znaleźć potwierdzenie tego czego chce. „To tak zrobić tak, tamto tak..." - tłumaczy mąż-mężczyzna i mówi coś o przyjęciach. A ja sięgam jeszcze dalej pamięcią, kiedy pierwszy raz rozmawiałam z Kirgizami

\footnotetext{
${ }^{8}$ Maladec - to określenie na osobę, która dobrze sobie z czymś radzi. Albo w danej chwili, albo ogólnie w życiu. W słowie tym kryje się zarówno pracowitość, jak i spryt czy odwaga.
} 
w Polsce i jak na moje powracające pytania o konie, młoda dziewczyna próbowała wyjaśniać, czym dla niej jest kultura Kirgizów. Mówiła o podawaniu herbaty przez kobiety, o gościach, a ja zastanawiałam się, o co właściwie jej chodzi - u nas też przyjmuje się $\mathrm{w}$ domu gości...

„W trójkę tam pojechaliśmy, poznaliśmy się, posiedzieliśmy. Wszystko. Na drugi dzień już zaczęliśmy się przygotowywać, planować”. Wtrącam, że „zięćc bierze udział we wszystkich porwaniach w rodzinie i przytaczam historię jak to jedna $\mathrm{z}$ bratowych, uciekając, wpadła $\mathrm{w}$ zaspę śniegu. Znowu się śmiejemy. W ogóle oboje zachowujemy się $w$ tej rozmowie jak Kirgizi - śmiejemy się przy takich słowach jak: „był mały skandal, trzeba zostać, a potem się ułoży”, bo jeśli się mówi o porwaniu, to "trzeba" się śmiać, no chyba że właśnie się w nim uczestniczy, wówczas wszystko wygląda inaczej...

Czekałam na tę rozmowę sześć lat, spisuję ją teraz i dostrzegam jak nasycona jest tamtym, nieznanym-znanym światem. Proszę koleżankę, by również odsłuchała zapis, gdyż nie mogę dosłyszeć części wypowiadanych słów - ale ona gubi się w narracji, nie wie co się kryje za stwierdzeniami „nie usiadła, zięć, toje-moje"... Ja wiem. Nie jest to oczywiście wiedza obiektywna czy relatywna, nie jest też anty-relatywna, tylko wiedza zbierana $\mathrm{z}$ każdym okrążeniem hermeneutycznego koła. Ale co z tą wiedzą zrobić, jak ją przekazać, tak by nie przyjmować perspektyw, by się nie śmiać, by stanąć poza własną zaściankowością, poza emocjonalną emancypacją zachodniego społeczeństwa? Czy za Cliffordem Geertzem mam przekonywać, że $\mathrm{w}$ antropologii chodzi o przyglądanie się smokom, a nie ich oswajanie (2004: 61)? Dlaczego się śmiałam? Dlaczego z przekonaniem kiwałam głową, gdy młody mąż Gulnary opowiadał o tym, że nie chce, by żona poszła do pracy, tylko urodziła mu jeszcze kilkoro dzieci? Dlaczego mu wierzyłam, gdy mówił o tym, że ona chciała za niego wyjść i wierzyłam jej, gdy mówiła, że nie była na to gotowa? Ciągle mi czegoś brakuje, dlatego tam powracam, szukam odpowiedzi, przyglądam się smokom, śmieję się z nimi i próbuję oswajać. Nie, nie smoki jednak, lecz siebie.

\section{Powrót filozofa, upadek błazna}

"Każda rozmowa, którą prowadzimy jest rozmową zupełnie nieszczerą" twierdził Robotycki (2014: 241). Jaka była moja rozmowa z Gulnarą w letniej kuchni? Jakie role odegrałyśmy w tej emocjonalnej wymianie i czy mogę myśleć o tamtym zdarzeniu w odniesieniu etnologicznym? Jednostkowy przypadek, na który składają się dwa pogłębione wywiady: Jej i Jego, oraz cała gama potwierdzeń, cała gama zapamiętanych obrazów. Może szukałam tych potwierdzeń? W tych dniach byłam z zewnątrz, bardzo, nie potrafiłam prowadzić rozmowy, wyłączałam się, jakbym patrzyła na wszystko przez szybę, na to zwyczajne życie. Rodzina: mąż, żona, dwójka dzieci i babka - matka męża. Praca w ogrodzie, powrót z pola, płacz dziecka, posiłek, sprzątanie, odwiedziny krewnych, rozmowy. Wszystko to znane w moim kręgu kulturowym, wszystko to potrafię nazwać, ale tylko w znanych 
mi kontekstach i kategoriach, lecz nie potrafię opisać tego, co się właściwie tam wydarzyło. Czy mogę coś rzetelnie opisać: niezarejestrowane słowa i obrazy, jako coś co chciałam zapamiętać i usłyszeć. Cóż zatem chciałam usłyszeć w tamtych dniach? Skąd ten bunt, bezradność, skoro każde postępowanie jest słuszne? Może z dysonansu poznawczego? „Antropologia nie ma zastosowań praktycznych, jest refleksją nad człowiekiem i kulturą" (Robotycki 2012). Odmienny sposób funkcjonowania w świecie różnych społeczności jest przecież opiewaną przez Geertza nierównowagą w świecie (2014: 61).

Zły okres w życiu Gulnary na kilka miesięcy przysłonił mi wszystko, o co próbowałam zawalczyć na polu etnologicznym, zanegowałam sprawczą postać kirgiskiej kobiety, dostrzegając jej niemoc na różnych życiowych etapach i w zmiennych okolicznościach. Jednak czyż nie jest to potwierdzeniem wygłaszanych wcześniej tez? Transformacja kobiety - od uprzedmiotowienia do odzyskania podmiotowości, do bycia szanowaną przez wszystkich staruszką, z której zdaniem wszyscy się liczą i której decyzji się nie podważa - jest długa. Widać, jak zyskuje tę podmiotowość po urodzeniu kolejnych dzieci, z wiekiem, z życiowym doświadczeniem, kolejnym świętem, ślubem, pogrzebem. Jednak bez tego pierwszego etapu proces nie może się dokonać. Szacunek kobieta buduje na okazywaniu szacunku innym: mężowi i jego rodzinie. Mogę buntować się wobec wewnętrznego sprzeciwu Gulnary, albo wobec widocznych przejawów męskiej dominacji, czy próby sprawdzenia Kirgiza, na co można sobie pozwolić z Europejką. Jednak czy to powie nam coś o sposobie bycia w świecie Kirgizów? Ten bunt zaświadczy tylko o mnie, o mojej kulturze, i o moich wartościach, marginalizując tych, których chciałam poznać, zrozumieć i opisać.

Moje dążenie do tego, by być jednocześnie filozofem i błaznem rozsypało się, gdy wyszłam poza obręb emocjonalności - nie znalazłam nowego wyjaśnienia. Ciągle podważając własne tezy, otrzymuję tę samą odpowiedź. Błądząc w kole hermeneutycznym, nie mogę na nowo opisać świata Innych. Te same zachowania zyskują nowe znaczenia, ale tylko na poziomie postrzegania. Jakby brakowało mi narzędzi do narracji. Opisując bowiem, krążę we własnym kręgu kulturowym, posiłkując się wyobrażeniami, definicjami, doświadczeniem mojego sposobu bycia w świecie. Robi to również mój każdy odbiorca. Ta ciągła transformacja tworzy nową wiedzę, która nie jest "wiedzą o kirgiskiej społeczności", jest tylko kolejnym wyobrażeniem o tej wiedzy. Dostrzegam przepaść między Nami a Nimi, między mną a Nami - współuczestnikami tej samej kultury. Jakby to doświadczenie antropologiczne było darem i ciężarem wyłącznie dla mnie.

\section{Zamiast zakończenia}

Zostałam etnologiem - to naprawdę ważne słowa, gdyż mimo że dyplom otrzymałam kilka lat temu, dopiero ostatniego lata zaczęłam tak się nazywać. Stało się to $\mathrm{w}$ momencie, gdy zaakceptowałam swoją niewiedzę, stan poszukiwania skazany na wieczne pytania i zmienne odpowiedzi. „Zewnętrzność reprezentacji 
zawsze rządzi się tym samym truizmem, że gdyby Orient mógł się sam zaprezentować, to by to zrobił - gromi Said - a skoro nie może, jest reprezentowany na potrzeby Zachodu..." (Said 2005: 55). Myślę o mojej zewnętrzności, tym, w jaki sposób reprezentuję świat kirgiskiej społeczności. Zadaję sobie pytanie, czy uczestniczę w „zachodnim” dyskursie i wymianie nie „prawdy”. Myślę o tym i wspominam wszystkie wspólnie zjedzone posiłki, uśmiechy, nieporozumienia, niepewne poruszanie się po wzajemnej niewiedzy, próby oswajania zrozumienia i buntu. Myślę o mojej gospodyni, która z całkowicie obcej osoby stała się zupełnie kimś innym, kiedy w mroku wieczornego podwórka poczułam się częścią rodzinnej egzystencji, spokojnej, niespiesznej i niespektakularnej chwili wspólnego bycia. Myślę też o obcych substancjach: pokarmie, powietrzu, kurzu; o obcych gestach i chwilach absolutnego niezrozumienia. Myślę i o tym, że nazywana tam jestem w miejscowych terminach pokrewieństwa, myślę o tym, że nadal jestem tam obcą - inną. Tak jestem Polką, tak mój dyskurs jest reprezentowany na potrzeby "Zachodu”, gdyż ten szeroko pojęty "Zachód" (tak samo etykietowany jak „Orient”) potrzebuje tej wiedzy, którą kreuję. To jest moja reprezentacja moja prawda, która może być poddawana krytykom i interpretacjom. Zatem dzisiaj dalej podtrzymuję, że kobieta w kirgiskiej społeczności jest podmiotem sprawczym i bardzo decyzyjnym, niezależnie od sposobu, w jaki się to przejawia, niezależnie od drogi, jaką musi przejść, by tym podmiotem się stała ${ }^{9}$.

\section{Literatura}

Bishop, R. (2014). Kaupapa Maori. Przezwyciężyć neokolonializm w badaniach społecznych, przeł. F. Rogalski. W: N. Denzin, Y. Lincoln (red.). Metody badań jakościowych. t. 1 (s. 166-205). Warszawa: Wydawnictwo Naukowe PWN.

Cruz Leo, C. (2013). Marriage in Form, Trafficking in Content: Non-con-sensual Bride Kidnapping in Contemporary Kyrgyzstan, http://inst.uchicago.edu/sites/inst.uchicago.edu/ files/uploads/2013\%20BA\%20Thesis_Cruz \%20Leo_PDF.pdf [dostęp: 18.08.2015].

Geertz, C. (2004). Zastane światto. Antropologiczne refleksje na tematy filozoficzne. Przeł. Z. Pucek. Kraków: Universitas.

Kołakowski, L. (1989). Kapłan i błazen. Rozważania o teologicznym dziedzictwie współczesnego myślenia. W: L. Kołakowski, Pochwała niekonsekwencji (s. 160-180). Warszawa: Niezależna Oficyna Wydawnicza NOWA.

Pietrowiak, S. (2014). Usiądź albo będziesz nieszczęśliwa... Perswazja, normy i nacisk społeczny, czyli o praktykach matrymonialnych w północno-zachodnim Kirgistanie, Normy, dewiacje i kontrola społeczna, 15, 289-309.

Robbins, R. (2013). Globalne problemy a kultura kapitalizmu. Przeł. S. Dymczyk. Poznań: Pro Publico.

Robotycki, Cz. (2014). Moja etnografia - spojrzenie z oddali. Oprac. J. Kowalewski, Konteksty, 1(304), 236-247.

Said, E. (2005). Orientalizm, przeł. Monika Wyrwas-Wiśniewska. Poznań: Zysk i S-ka.

9 Zainteresowanych odsyłam do mojego artykułu Usiądź albo będziesz nieszczęśliwa... Perswazja, normy i nacisk spoteczny, czyli o praktykach matrymonialnych w pótnocno-zachodnim Kirgistanie (Pietrowiak 2014). Znajdzie tam Czytelnik niektóre z poruszanych tu kwestii dotyczących porwań panien w Kirgistanie oraz literaturę dotyczącą tego zjawiska. 


\section{Źródła filmowe}

Pamięć Uniwersytetu: Nieoczywisty antropolog, rzecz o prof. Czestawie Robotyckim, reż. M. Zborek, 2014, Kraków: Uniwersytet Jagielloński.

\section{SUMMARY}

The vicious circle of a clown, or a step back from Gulnary's summer kitchen

The paper is a reflection on participating in distinct cultures while conducting anthropological research. The observations, recorded by me in my fieldwork diary, contain feelings, memories and judgements, resulting from my personal involvement and experiences, and serve as a pretext for considering anthropological knowledge and the way in which it is created. The snapshots excerpted from some events and interviews do not concern a single character, although they create a consistent story - an image of Kyrgyz social life, in which marriage by abduction is still practiced. Among various practices found in Kyrgyz families, I continually experience and interpret this particular custom, which is hard to accept in the "Western world". Most of the questions I raised are seemingly without answers. However, dense descriptions of events, together with large quantity of examples and observations should bring the readers to their own conclusions. The paper is based on field studies in 2006, 2008, 2009 and 2014 in the north-western Kyrystan, in district of Talas Province.

Keywords: Kyrgyzstan, marriage by abduction, anthropological knowledge, ethnographic experience, methodology and ethics in field research 